\title{
REFABRICATION OF MACHINE TOOLS PROBLEMS SPECIFIC TO THE INCREASE OF THE CUTTING SPEEDS
}

\section{PRODAN, D. \& GHEORGHIU, H.}

Abstract: The present paper presents some theoretical and experimental research regarding the cooling systems for machine tools. Considering the fact that the temperature calculus depends on a lot of factors, it is necessary that we must check and correlate the theoretical results to the experimental measures.

This work presents the theoretical and experimental research performed when refabricating a Vertical Lathe SC 14 CNC type, for which the maximum speed of the table has been increased by more than 100\%.

The machine has been intended to rough and finish machining of aluminum made workpieces.

Key words: Machine-Tools, Refabrication, Cooling
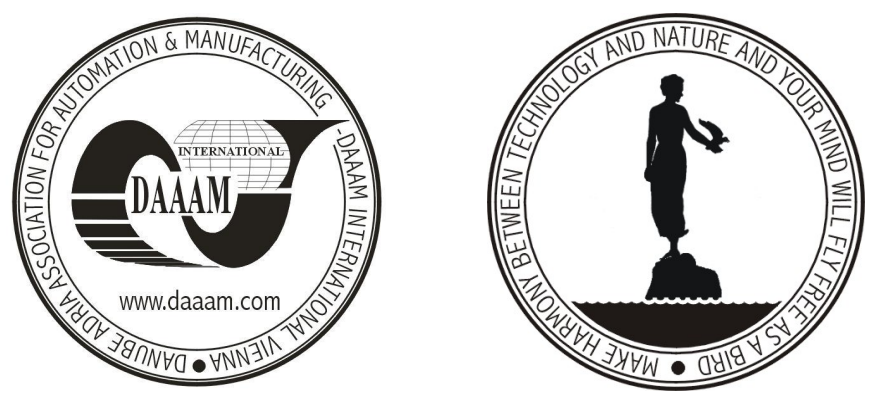

Authors' data: Assoc. Prof. Dr. Eng. Prodan, D[an]; Prof. Dr. Eng. Gheorghiu, $\mathrm{H}$ [oria], Universitatea Politehnica Bucuresti, Splaiul Independentei Nr.313, Bucuresti, Sector 6, Romania, prodand2004@yahoo.com, horia100@hotmail.com

This Publication has to be referred as: Prodan, D. \& Gheorghiu, H. (2007). Refabrication of Machine Tools Problems Specific to the Increase of the Cutting Speeds, Chapter 16 in DAAAM International Scientific Book 2007, B. Katalinic (Ed.), Published by DAAAM International, ISBN 3-901509-60-7, ISSN 1726-9687, Vienna, Austria

DOI: 10.2507/daaam.scibook.2007.16 